\title{
TEACHER TALK IN YOUNG LEARNERS' CLASSROOM INTERACTION
}

\author{
Silpia Rahayu \\ English Department, Faculty of Language Education, \\ Institut Keguruan dan Ilmu Pendidikan (IKIP) Siliwangi, Indonesia \\ E-mail: silviarahayu41@yahoo.com \\ Trisnendri Syahrizal \\ English Department, Faculty of Language Education, \\ Institut Keguruan dan Ilmu Pendidikan (IKIP) Siliwangi, Indonesia \\ E-mail: trisnendri@gmail.com
}

APA Citation: Rahayu, S., \& Syahrizal, T. (2020). Teacher talk in young learners' classroom interaction. Indonesian EFL Journal, 6(1), 89-96. doi: 10.25134/ieflj.v6i1.2651.

Received: 19-03-2019

Accepted: 21-06-2019

Published: 01-01-2020

\begin{abstract}
In English Foreign Language (EFL) class, learners are not familiar with English in daily conversation, except several learners who have background in using English in their home or environment. Therefore, teacher plays a significant role as facilitator to introduce them into the language. This study aims to describe teacher talk and students talk as well as the way teacher talk is realized in young learners' classroom interaction by applying a descriptive method. The fifth grade classroom interaction at a primary school in Majalengka was recorded as the sample of the analysis. The data gained through observation was in the form of transcribed interaction. Besides, interview was also used to collect the data. To analyze the data, this study employed Flanders Interaction Analyzed Categories. Upon analyzing the data, the following findings are identified; 1) Accepting feeings (2 occuraces); 2) Encouragement (17 occuraces); 3) Accepting or using ideas of learners (54 occuraces); 4) Asking questions (142 occuraces); 5) lecturing (49 occuraces); 6) Giving directions (53 occuraces); 7) Criticizing learners behaviour (9 occuraces); 8) Learners-response (151 occuraces); 9) Learners-initiation (7 occuraces); and 10) Period of silence or confusion (8 occuraces). Finally, the use of similar activity for too long will make young learners feel bored, therefore, teacher needs to provide variety and more meaningful activities. In this case, teacher can use various techniques to stimulate learners' response. Besides, creating group discussion will give more opportunity to the learners to talk and learn from their peers.
\end{abstract}

Keywords: teaching speaking; teacher talk; students talk; young learners.

\section{INTRODUCTION}

As mandated in Act No. 19 of 2005, teaching English to young learners shall be incorporated into the elementary school curriculum as local content from grade 6. In Indonesia, English is taught as a foreign language. In English Foreign Language (EFL) class, learners are not familiar with English in daily conversation, except several learners who have background in using English in their home or environment. Therefore, teacher plays a significant role as facilitator to introduce them into new language.

To teach English to young learners optimally, teacher needs to create an interactive teaching strategies in language classroom. Interaction is one of the important factors for language teachers. Interaction in language class is different from other interactions. In language classroom, interaction is a process of learning language (Husnaini, 2005). The interaction in the form of communication and language helps young learners to become competent and effective learners. This view is generally emphasized on childhood education. Thus, most of the teachers consider talking to and with young learners as an important part of their works.

Brown (2001) says that a teacher-centered or teacher-fronted classroom is appropriate for some of classroom time. Teacher responsibility is to keep the interaction flowing smoothly and efficiently. Not surprisingly, classroom observation has revealed that teachers tend to do most of the talking. Nunan (1989) explains that in some language classroom, it has been shown that the teachers talk up to 89 percent of the available time, it is more dominant than learners talk. Those statements means that learners talk is less than teacher talk. It provides learners with less opportunity to speak. Realizing that teacher domination in English Foreign Language class is not very good for improving learners's ability to talk in the targets language, teachers has to 
manage their talk into appropriate proportion. It means that they have to make learners talk more. Learners talk can be influenced by kinds of teachers questions. Learners will probably say "yes" or "no" if teacher does most displayed questions so that the learners will not be supported by the teacher to talk in English.

\section{Young learners' classroom interaction}

Young learners' classroom in this study refers to the classroom where the learners are in the age between 5-11 years old. In young learners' classroom, the interaction cannot be predicted by teachers because they have special characteristics. Cameron (2001) states children are often more enthusiastic and lively as learners. If the instruction cannot be understood by them, they may become so much silent or, in contrast, they can also become chaotic. They will have got an activity even when they do not really understand why and how. However, they also lost interest more quickly and are less able to keep themselves motivated on the task they find difficult. Teachers have to manage young learners classroom more than adult learners classroom. They have to try to build intimate relation with them so the students feel that their teacher are friendly. However, teachers have to make them dicipline, to make them know that they must follow the rules. They try to use the target language to talk and to teach as well as praise them.

It is in line with Wood (1986) who says in some classrooms, children scemed relatively active and responsive. They talked a good deal, asked questions and contributed to discussions. In others, children seemed rather shy, unwilling to tell something and ignore, and do not want to give information to the teacher. They spoke little and often in short phrases or even monosyllables. Therefore, children who are familiar with classroom values and practices tend to be more confident in their interaction with others in the classroom.

\section{Teacher talk}

Teacher talk is a kind of language used by the teacher for instructions in the classroom. Ellis
(1986) explains that teacher talk is a special language that teachers used when addressing L2 learners in the classroom.. Ellis (1986) also says that the language the teachers address to L2 learner is treated as a register, with its own specific formal and linguistic properties.

Referring to the description, it can be concluded that teacher talk is a special language used by teacher for instructions in the classroom with its own specific formal and linguistic properties. Teacher has many roles in young learners classroom; the teacher's speech occupies a special place in the language classroom. For example, teacher plans activities designed to facilitate learners' acquisition and use of the target language. At the same time, however, teachers use the target language as the principal means for giving instruction and directions, modeling target language patterns and giving feedback on learners' performance.

\section{METHOD}

Descriptive qualitative approach was applied in this study. According to Moleong (2002), qualitative research is aimed at understanding the phenomena of what is experienced by the subject of research, such as behavior, perception, motivation, holistic actions, qualitatively using words and language in natural contexts by using various scientific methods. In this study, the teacher's perception as the subject of study was investigated to know how her teaching and learning process in her class. As stated by Creswell (2012), qualitative is used to understand a phenomenon by focusing on the total picture rather than breaking it into variable.

\section{RESULTS AND DISCUSSION}

This section presents the results of the study dealing with the data taken from the observation. The results cover the percentage of teacher talk and learner talk as well as the way teacher talk is realized in young learners classroom interaction.

Table 1. Observation result

\begin{tabular}{ll}
\hline Steps taken by the teacher & Steps taken by the students \\
\hline good morning students! & - Good morning Mam! \\
- How are you today? & - I'm fine thank you, and you? \\
- What day is today? & - Monday \\
- Ok, now conth in inue the lesson. & - Akan \\
$\begin{array}{l}\text { About what? About will, will apa itu } \\
\text { will? }\end{array}$ \\
\hline
\end{tabular}




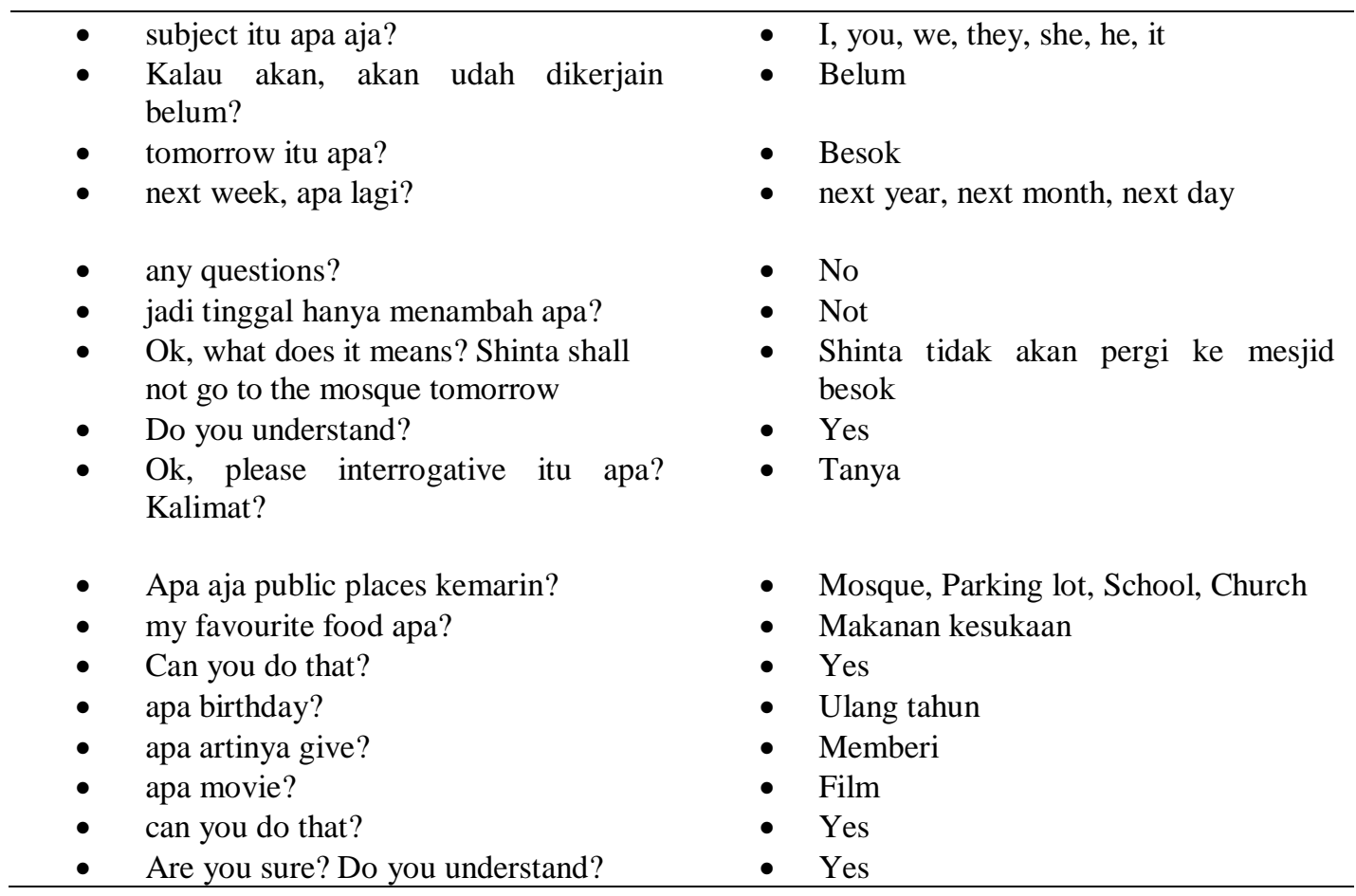

\section{Teacher talk}

Teacher talk was categorized into seven steps, namely accepting feeling, encouragement, accepting or using ideas of student, asking questions, lecturing, giving directions, and criticizing.

\section{Accepting feeling}

This category occured when teacher responded learners' act, accepted and clarified learners' behaviour or attitude with non-threatening manner. In the observation, the teacher used this act when learners did negative behaviour, seemed uncomfort, and moved from one seat to another seat. Teacher accepted their attitude with nonthreatening manner by humourous way. The activity was realized as many as two occuraces.

\section{Encouragement}

There are many ways in giving the rewards for learners, for example by saying good, great, that is right, and excellent. Those are categorized as immediate reward. In this context, the teacher liked to give immediate verbal praises to the learners who can answer the given questions, such as ok, good, and great. Based on Paul (2001), it is best to make comments that are directed at the work itself rather than at the child. Teachers can be warm to the learners and show an interest in what they have said, written, or drawn, rather than saying "well done!". It can be seen in the observation that teacher also used this way when she gave a comment for one of the learners that have written something as a good example for her classmate. The teacher also used non- verbal praise, such as giving applause to encourage learners. Encouragement can also be used to motivate learners when they are ashame to answer question. It was shown in the observation when teacher tried to motivate learners with humourous way.

The teacher used praise verbally and nonverbally. Verbally, the teacher used words, such as good and great. Non-verbally, the teacher gave applause to the learners. Young learners, especially in the lower grade, like to be given reward. It will motivate them to learn. The activity was rated 17 tallies.

\section{Accepting or using ideas of the students}

By accepting or using ideas of the learners, teacher clarified, built, interpreted, summarized, rephrased, and developed ideas suggested by learners. When teacher rephrased the learners' ideas, the ideas are still recognized as being learners' contributions. Accepting or using ideas of the students was rated 54 tallies. From the observation, it can be analyzed that the learners imitated the teacher's words as a response to the teacher's initiation.

\section{Asking questions}

There are two types of teacher's questions which were investigated in this study, referential and display questions (Long \& Sato as cited in Xiou Yan, 2006). Referential questions refered to the quetions which the teacher did not know the answers and could gain various subjective information, while display questions refered to the ones that teacher knows the answer. It was 
aimed to bring learners to think about the subject under discussion. Such questions that the teacher asked usually for comprehension checks, confirmation checks, or clarification type based on observation transcript. The activity was realized in young learners classroom interaction as many as 142 occuraces. The types of question asked by the teacher are presented in Table 2 .

Table 2. Question types

\begin{tabular}{ccc}
\hline Question Types & Acts & Total \\
\hline Displays & $5,7,9,13,17,21,25,27,33,39,41,43,45,47,49$, & 132 \\
& $51,53,58,62,64,70,74,78,80,82,86,88,90,98$, & \\
& $102,104,106,108,110,112,114,116,118,120$, & \\
& $124,126,130,132,134,136,138,142,146,148$, & \\
& $150,152,154,156,158,160,162,164,167,169$, & \\
& $171,174,176,178,181,184,186,190,192,194$, & \\
& $196,198,200,204,208,212,214,216,218,220$, & \\
& $222,224,228,230,232,236,238,241,246,251$, & \\
& $253,255,272,274,276,278,286,288,294,300$, & \\
& $302,306,308,310,314,317,321,325,331,335$, & \\
& $337,339,341,343,347,349,357,359,365,371$, & \\
& $373,375,377,379,382,388,390,392,394,396,398$ & 10 \\
Referential & $66,76,94,118,128,210,262,296,367,386$ & 142 \\
\hline
\end{tabular}

\section{Lecturing}

In lecturing, the teacher gave facts or opinions about the contents or procedures, expressed her own ideas, and gave her own explanation about something related to the content of the lesson. In this case, the learners were recognized as young learners, so the teacher used as much as new language as possible to provide language input. This was the way teacher lecturing learners. Teacher sometimes pre-teachers structures that would be studied later or simply offers learners more opportunities to learn new expressions in context. This was used to increase their own vocabulary based on the topic discussed. The activity was realized as many as 49 tallies.

The classroom activities tried to make a routine to the learners to use English as the instructions and language classroom. The teacher usually used songs to introduce the context and the topic that will to be taught. Actually, game can also support learning, however, the teacher used asking-answer questions as a game because of the big number of learners. It made the learners interested in involving in the learning activity. In addition, the teacher sometimes used role play, for example between the aplicant and the manager, asking for biodata and spelling name.

\section{Giving direction}

The teacher plays many roles in the class. The first role is as a director in the classroom setting, while teacher's direction is very important to keep the teaching and learning process flowing smoothy and efficiently. This category was mostly used by teacher in the lesson. In the observation transcript, negotiation and repair played a part in the classroom interaction. The teacher tried to make her directions more understanable by using repitition.

The teacher chose more common words, simple grammar structure and short sentences to make the learners involved to the material context. Giving direction was realized as many as 53 tallies. (obs. 25/07/19, acts no. 45, 64, 80, 84, $106,126,140,150,158,160,167,169,171,180$, $181,184,196,204,220,238,259,262,266,296$, $300,302,304,306,321,325,341,353,355,357$, 363,367 , and 379). Besides, the teacher also directed the learners to manage the class by using intructions. (obs. 25/07/19, acts no. 96, 152, 162, $206,212,230,243,250,345,359,361,379,384$, and 400).

\section{Criticizing}

There are two types of criticizing, namely criticizing the learners' behaviour and criticizing unacceptable learners' response. The teacher criticized learners' behaviour, such as rejecting learners' behaviour, trying to change the nonacceptable behavior, communicating anger, displeasure, and annoyance with what the learners are doing (obs. 25/07/19, acts no. 68, 132, 136, 202, 272, and 329). The teacher also criticized some unacceptable learners' response; corrected learners' pronunciation (obs. 25/07/19, acts no. 255 and 317). The teacher used humourous way to criticize so that learners did not feel unmotivated. As shown in the transcript (obs. $25 / 07 / 19$, acts no. 351), the teacher criticized a learner who wanted to answer question which was 
always the same and asked other learners to involve in the discussion "jangan Miras ah, bosen (smiling), coba yang lainnya, Reza, no 1, kalo kamu bisa no 1, PR itu gampang, nilainya seratus." The activity was rated as many as 9 tallies. The realization of teacher talk in young learners' classroom interaction is summarized in Table 3.

Table 3. The realization of teacher talk in young learners classroom interaction

\begin{tabular}{|c|c|c|}
\hline Category & Tallies & Total \\
\hline Accepting feelings & II & 2 \\
\hline Encouragement & Н世 Ю世 I円HI & 17 \\
\hline $\begin{array}{l}\text { Accepting or using ideas of } \\
\text { learners }\end{array}$ & 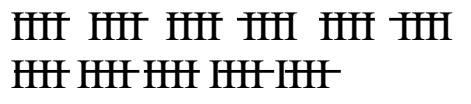 & 54 \\
\hline Asking questions & 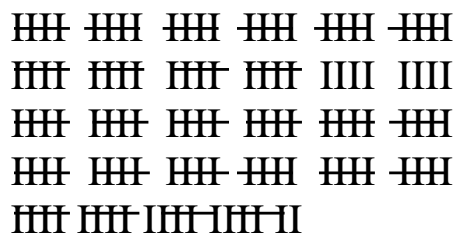 & 142 \\
\hline Lecturing & 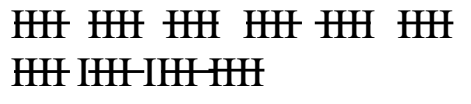 & 49 \\
\hline Giving directions & 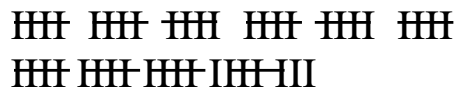 & 53 \\
\hline Criticizing learners behaviour & HH H\# & 9 \\
\hline Period of silence or confusion & H\# III & 8 \\
\hline Total & & 326 \\
\hline
\end{tabular}

\section{Learner talk}

In addition to teacher talk, the category of Flanders Interaction Analysis also includes learner talk. Based on FIAC, the category of learner talk can be divided into two, response and initiation.

\section{Learners-response}

Response is the first category of learners talk. The learners usually responded the teacher in a limited or available previously shaped answer. It can be identified from the analysis that the learners usually answered the teacher's questions or responded to the teacher's directions by imitating what the teacher has said in chorus. The language produced by the learners was simple sentence or one-word response, except several learners who were asked individually by the teacher to make a sentence. The activity was realized as many as 151 occuraces.

Obs. $25 / 07 / 19$, acts no. $6,8,10,12,18,20$, $22,24,28,30,31,32,34,36,38,40,42,44,48$, $50,52,54,59,61,62,63,65,67,71,73,75,79$, $81,83,85,87,91,99,103,105,107,109,111$, $113,117,121,123,125,127,135,137,143,145$, $147,149,151,153,155,157,161,170,175,177$, 179, 185, 187, 189, 191, 193, 195, 199, 203, 205,
$209,213,215,217,219,221,223,225,227,229$, $231,235,237,239,240,242,247,252,256,258$, $263,265,267,269,271,273,275,277,279,281$, $283,285,287,289,291,293,297,299,303,305$, $307,309,313,315,316,318,320,324,326,332$, $334,336,338,340,342,344,346,348,358,360$, $366,368,370,372,374,376,378,380,383,387$, 389, 391, 393, 395, 397, 399, and 401.

\section{Learner-initiation}

Initiation is another category of learners talk. It occurs when the learners respond to the teacher's direction with learner's own ideas, opinion, reactions and feeling. After the observation, it can be concluded that the learners did some initiation, such as when they wanted to get the teacher's permission to go somewhere and when the learners gave opinion about the topic discussed. Same as learner-response, the languages which were produced in the initiation also one-word or just simple sentence. (obs. 25/07/19, acts no. 56, $57,132,245,260,261$, and 381$)$. The activity was rated 7 tallies.

The realization of teacher talk in young learners' classroom interaction is summarized in Table 4. 
Table 4. The realization of learners talk in young learners classroom interaction

\begin{tabular}{|c|c|c|}
\hline Category & Tallies & Total \\
\hline \multirow[t]{6}{*}{ Learners-response } & HII HH HH HH HH HH & 151 \\
\hline & HEH HH HIf HH HH HH & \\
\hline & 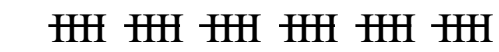 & \\
\hline & HII IHI 円H HH \#H IIII & \\
\hline & 円H 円IIH円HI円 & \\
\hline & HIfI I & \\
\hline \multirow[t]{2}{*}{ Learners-initiation } & HfI II & 7 \\
\hline & Total & 158 \\
\hline
\end{tabular}

The precentages of teacher talk and learner talk

The total precentage of teacher talk that has been observed was $66 \%$ of the classtime. It means that the teacher did most of the talking during the lesson. The teacher used more indirect influence (accepting feeling, encouragement, accepting or using ideas of the learners, and asking questions) than direct influence (lecturing, giving directions, and criticizing). It was $44,6 \%$ and $21,4 \%$. Meanwhile, the percentage of learner talk was about $32 \%$. The learners mostly did response than initiation.

Based on the proportion of teacher talk time, it can be inferred that teacher's domination emerged on the lesson. It occured because the learners as young language learners very depended on the teacher as the model of language. In other words, the teaching and learning process was still teacher-centered. The distribution of teacher talk influenced learner talk. The proportion of $66 \%$ and $32 \%$ may not be an ideal proportion. However, the teacher always gave an opportunities for learners to talk by giving questions or directions. Therefore, the learners could explain or produce some words orally related to the topic discussed. It could reduce teacher talk time. The teacher gave opportunity to the learners to talk by asking questions. He asked easier questions first then followed by more difficult questions. In addition, the teacher also gave directions to the learners to mention simple sentence based on the given topic.

Based on the transcript, it was found that the teacher did her best to build an interactive classroom interaction. The teacher encouraged learners to talk by using various ways. It can be concluded that the teacher categorized as an interactive teacher. The teacher was not totally used English to teach children. She scaffolded them to the pattern being taught by translating new word and speaking slowly. She also tried to give routine so that they can directly respond to the teacher by using English at least in the English class.

Based on those description, it can be inferred that generally, the teacher applied the principle of interactive class. The use of concrete things and songs to introduce new material was meaningful for young learners and engage them to the context being taught. She also supported her teaching by humourous way, both in criticizing and explaining the material. It was done by the teacher because she wanted to create intimate relation with the learners, supported the learners to respond, and also created warm and friendly environment so that children can enjoy the learning process and involved in the classroom interaction.

As previously mentioned, this study conducted tallying and calculating procedures to get the percentage of teacher talk and learners talk. The total tallies are drawn in Table 5. 
Table 5. Number of tallies for each category

\begin{tabular}{|c|c|c|c|c|c|}
\hline \multicolumn{3}{|c|}{ TEACHER TALK } & \multicolumn{3}{|c|}{ LEARNERS TALK } \\
\hline Category & Tallies & Total & Category & Tallies & Total \\
\hline Accepting feelings & II & 2 & $\begin{array}{l}\text { Learners- } \\
\text { response }\end{array}$ & 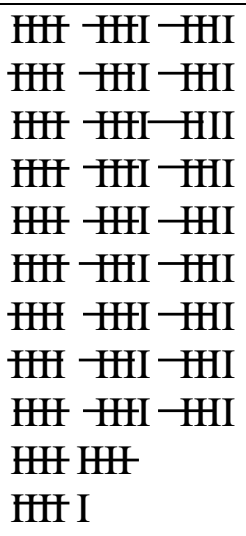 & 151 \\
\hline Encouragement & HIH HI IHIII & 17 & $\begin{array}{l}\text { Learners- } \\
\text { initiation }\end{array}$ & HIff II & 7 \\
\hline $\begin{array}{l}\text { Accepting or using } \\
\text { ideas of learners }\end{array}$ & 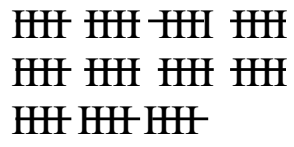 & 54 & & & \\
\hline Asking questions & 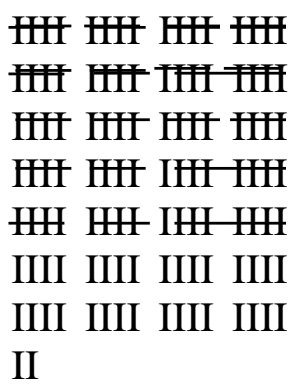 & 142 & & & \\
\hline Lecturing & 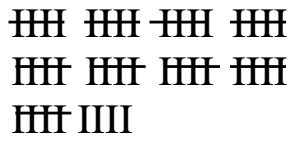 & 49 & & & \\
\hline Giving directions & 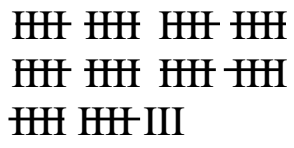 & 53 & & & \\
\hline $\begin{array}{l}\text { Criticizing learners } \\
\text { behavior }\end{array}$ & \#\# IIII & 9 & & & \\
\hline $\begin{array}{l}\text { Period of silence or } \\
\text { confusion }\end{array}$ & HIf III & 8 & & & \\
\hline Total & & 326 & & & 158 \\
\hline
\end{tabular}

\section{CONCLUSION}

The realization of teacher talk in young learners' classroom interaction was identified as follows; 1) Accepting feeings (2 occuraces); 2) Encouragement (17 occuraces); 3) Accepting or using ideas of learners (54 occuraces); 4) Asking questions (142 occuraces); 5) lecturing (49 occuraces); 6) Giving directions (53 occuraces); 7) Criticizing learners behaviour ( 9 occuraces); 8) Learners-response (151 occuraces); 9) Learnersinitiation (7 occuraces); and 10) Period of silence or confusion (8 occuraces).
The proportional of teacher talk and learner talk is $66 \%: 32 \%$. It means that the teacher did most of the talking on the lesson. Here, the learners mostly used response than initiation because the teacher usually initiated the interaction.

\section{REFERENCES}

Brown, H. D. (2001). Teaching by principle: An interactive approach to language pedagogy. London. Prentice Hall. 
Silpia Rahayu \& Trisnendri Syahrizal

Teacher talk in young learners' classroom interaction

Cameron, L. (2001). Teaching languages to young learners. Cambridge: Cambridge University Press.

Creswell, J. W. (2012). Educational research: Planning, conducting and evaluating quantitative and qualitative research. New York: Pearson.

Ellis, R. (1986). Understanding second language acquisition. Oxford: Oxford University Press.

Husnaini. (2005). Teacher talk and learner talk in classroom interaction: An interaction analysis to an English language class at SMPN 29 Bandung. Unpublished Thesis. State Islamic University of Sunan Gunung Djati Bandung.
Nunan, D. (1989). Understanding language classroom: A guide for teacher initiated action. London: Prentice Hall International.

Paul, D. (2001). Teaching English to children in Asia. Longman Asia ELT.

Wood, D., \& Wood, H. (1986). Teaching and talking with deaf children. London: John Wiley and Sons Ltd.

Xiou-yan. (2006). Teacher talk and EFL in university classroom. Retrieved from www.Asean-efljournal.com/thesis_Ma_Xiou.pdf. 